\title{
ВИВЧЕННЯ ВПЛИВУ БІОПРЕПАРАТІВ ЗА РІЗНИХ НОРМ ВНЕСЕННЯ НА ПРОДУКТИВНІСТЬ ПШЕНИЦІ ОЗИМОЇ В УМОВАХ ПІВНІЧНОГО СТЕПУ УКРАЇНИ
}

\author{
${ }^{1}$ Чугрій Г. А., завідувач відділу технологій виробництва сільськогосподарської продукції \\ ${ }^{1}$ Вінюков О. О., к.с.-г.н, с.н.д., директор \\ ${ }^{1}$ Донецька державна сільськогосподарська дослідна станиія НААН України \\ Україна, Покровськ \\ ${ }^{2}$ Гирка А. Д., д.с.-г.н., професор, заступник директора з наукової роботи \\ ${ }^{2}$ Інститут зернових культур НААН, Украӥна, Дніпро
}

DOI: https://doi.org/10.31435/rsglobal_sr/31012020/6867

\begin{abstract}
ARTICLE INFO
Received 14 November 2019

Accepted 09 January 2020

Published 31 January 2020

\section{KEYWORDS}

technology, winter wheat, variety, version of the study, biometric indicators, crop structure, crop capacity.

ABSTRACT

The article investigated the effect of biological products for different application rates on the productivity of winter wheat in the northern steppes of Ukraine. The technology of growing winter wheat has been determined, which is based on optimizing a huge number of different conditions that affect the formation of high grain productivity of the required quality. Growing technologies pay great attention to sowing dates, which directly affect not only the quantity and quality of the crop, but also the formation of plant resistance to many adverse factors. The weather conditions on which the studies were conducted are analyzed. The biometric indicators of winter wheat plants were revealed, namely: tillering coefficient, coefficient of secondary roots, number of grains in an ear, weight of a thousand seeds. The yield of winter wheat was determined depending on the proposed experimental design.
\end{abstract}

Citation: Чугрій Г. А., Вінюков О. О., Гирка А. Д. (2020) Vyvchennia Vplyvu Biopreparativ za Riznykh Norm Vnesennia na Produktyvnist Pshenytsi Ozymoi v Umovakh Pivnichnoho Stepu Ukrainy. Science Review. 1(28). doi: 10.31435/rsglobal_sr/31012020/6867

Copyright: (C) 2020 Чугрій Г. А., Вінюков О. О., Гирка А. Д. This is an open-access article distributed under the terms of the Creative Commons Attribution License (CC BY). The use, distribution or reproduction in other forums is permitted, provided the original author(s) or licensor are credited and that the original publication in this journal is cited, in accordance with accepted academic practice. No use, distribution or reproduction is permitted which does not comply with these terms.

\section{Постановка проблеми в загальному вигляді.}

Технологія вирощування пшениці озимої грунтується на оптимізації величезної кількості різних умов, які мають вплив на формування високої зернової продуктивності необхідної якості.

Велика кількість різних, відмінних від традиційної, технологій, що з'явилися останнім часом, свідчить про можливість досягнення основної мети - підвищення валових зборів зерна. Для цього є величезний арсенал всіляких агротехнічних прийомів. Кожен з них має не тільки прямий, а й опосередкований вплив, який не завжди позитивно позначається на адаптаційних можливостях рослин.

Технологія вирощування пшениці озимої досить лабільна i враховує грунтовокліматичні умови і біологічні особливості культури 3 тим, щоб максимально розкрити потенційні можливості сортів. 3 іншого боку - тільки за умови вирощування пшениці озимої 3 урахуванням сортової специфічної реакції на основні агротехнічні прийоми можна очікувати на найповнішу віддачу від нових сортів [5; 6]. 
Пшениця озима має специфічну реакцію на умови зростання, обумовлену біологічними особливостями великої кількості видів і різновидів, екологічних типів і форм. Різні сорти пшениці проявляють не однакову реакцію як на окремі агротехнічні прийоми так і на комплекс технологічних заходів вирощування у конкретно взятому році. Так, суттєвий вплив на ріст, розвиток і формування продуктивності рослин пшениці озимої здійснює попередник [6].

В будь-якій технології вирощування велика увага приділяється строкам сівби, які безпосередньо впливають не тільки на кількість і якість врожаю, але і на формування стійкості рослин до багатьох несприятливих факторів $[1 ; 3]$. Так, з одного боку, у посівах за ранніх строків сівби рослини більше уражуються збудниками хвороб, шкідниками, у них частіше пошкоджуються найбільш продуктивні головні пагони, а з іншого - пізні посіви в більшості випадків виявляються слаборозвиненими, погано кущяться, більше схильні до механічних пошкоджень при перезимівлі, сильніше страждають від суховіїв навесні та влітку [1; 7].

Аналіз останніх досліджень і публікацій.

Вагомий внесок у вирішення проблеми збільшення врожайності та поліпшення якості зерна озимої пшениці в різні роки зробили такі вчені як А. І. Задонцев, В. І. Бондаренко, 3. Б. Борисонік, Г. Р. Пікуш, В. Г. Нестерець, А. В. Черенков, І. Д. Ткаліч, Л. Ф. Демішев, А. Г. Мусатов, С. М. Каленська, М. А. Бобро, І. І. Ярчук, М. І. Пихтін, Ю. Я. Сидоренко, М. М. Солодушко та багато інших. Проте, за нинішніх умов глобального потепління і погоднокліматичних змін актуальним $є$ обгрунтування і розробка заходів послаблення негативного впливу різких перепадів температур та дефіциту грунтової вологи. Важливе значення має виявлення впливу біопрепаратів за різними нормами внесення, які задовільнять збільшення продуктивності пшениці озимої [2; 3].

Зокрема, дослідженнями проблеми ефективності виробництва зернових культур займались такі українські вчені, як В.Г. Андрійчук, І.О. Бистрова, С.С. Бакай, О.В. Боднар, Н.О. Єфремова, П.Т. Саблук, О.В. Олійник, А. І. Степанов, Ю.Л. Філімонов, О.М. Шпичак, О.В. Шубравська.

Мета статті полягає в вивчені впливу біопрепаратів за різних норм внесення на продуктивність пшениці озимої в умовах Північного Степу України.

Постановка завдання. Експериментальні дослідження проводили у продовж 2018-2019 pp. на дослідних ділянках Донецької державної сільськогосподарської дослідної станції НААН, які розташовані в центральній частині Донецької області у Великоновосілківському районі, с. Розлив.

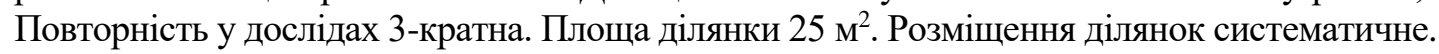

Попередник чорний пар. Дата посіву пшениці озимої - 24.09.2018p.

Сорт пшениці озимої Перемога, норма висіву складала 4,5 млн. схожого насіння на гектар.

Грунт - чорнозем звичайний малогумусний, важко суглинковий. Валовий вміст основних поживних речовин: $\mathrm{N}-0,28-0,31 \%$, P2O5 - 0,16-0,18 \%, К2О - 1,8-2,0 \%, вміст гумусу в орному шарі $-4,5 \%$, pНсол-6,9. Обробіток грунту звичайний, загальноприйнятий в господарствах області.

Схема дослідів передбачала обробку насіння біопрепаратами:

1. Контроль (без обробки)

2. МікоФренд 1 л/т (насіння)

3. Меланоріз 1 л/т (насіння)

4. ГуміФренд 1 л/т (насіння)

5. МікоФренд 1 л / + ГуміФренд 0,8 л/т (насіння)

6. Меланоріз 0,5 л/т + ГуміФренд 0,8 л/т

7. МікоФренд 1 л/т+ ХелпРост насіння 1 л/т (насіння)

8. Меланоріз 0,5 л/т + ХелпРост насіння 1 л/т (насіння)

9. ГуміФренд 0,4 л/га (початок трубкування)

10.ГуміФренд 0,5 л/га (фаза прапорцевого листка)

Після відновлення весняної вегетації проводилось підживлення мінеральними добривами дозою N58.

Також, для захисту рослин протягом вегетації, проводилось обприскування посівів наступними пестицидами: фаза кінець кущіння бакова суміш: Прима Форте 0,7 л/га + Амістар Екстра 0,5 л/га + Коннект 0,5 л/га; фаза колосіння бакова суміш: Альто супер 0,5 л/га + Енжіо 0,18 л/га.

Урожайні дані перерахували на 14 \% вологості із урахуванням засміченості зернової маси. 
В дослідах проводили фенологічні, агрометеорологічні спостереження і обліки, визначали структуру врожаю. Врожай збирали по ділянках комбайном Sampo-130. Статистична обробка врожайних даних проведена за Б. А. Доспеховим «Методика Полевого опыта» [5].

Виклад основного матеріалу дослідження. Територія землекористування на якій проводили дослідження характеризується в цілому континентальним кліматом з жарким сухим літом, малосніжною з відлигами зимою. За багаторічними даними середньорічна температура повітря складає 7,6-8,0 $0^{\circ}$. Найжаркіший місяць - липень (середньобагаторічна температура повітря $+21,2^{\circ} \mathrm{C}$ ), найхолодніший - січень (середньобагаторічна температура $-5,8^{\circ} \mathrm{C}$ ). Максимальна температура повітря $+42^{\circ} \mathrm{C}$, мінімальна $--39^{\circ} \mathrm{C}$.

Середньорічна кількість опадів складає 542 мм, максимум опадів припадає на червень (середнєбагаторічне 56 мм), які випадають у вигляді злив, мінімум - на березень (середнєбагаторічне 35 мм). Гідротермічний коефіцієнт 0,9. Запаси вологи в грунті формуються під впливом осінньо-весняних опадів. Взимку частина опадів випадає у вигляді снігу, який захищає грунт від сильного промерзання і служить джерелом накопичення вологи. Середня висота снігового покриву становить 14 см, максимальна -23 см, мінімальна -3 см.

Відносна вологість повітря в літні місяці порівняно низька (58-63\%), що негативно позначається на вегетації рослин. Кількість діб з відносною вологістю повітря $30 \%$ і нижче - 60 за рік.

Характерне панування вітрів північно-східного (40\%) напрямку. Вони часто носять характер суховіїв і зумовлюють грунтову посуху. За період з квітня по вересень буває в середньому 79 діб із суховіями, з них 42 доби - слабкої, 24 доби - середньої інтенсивності, 9 діб з інтенсивними і 4 доби 3 дуже інтенсивними суховіями. Відносна вологість повітря в період суховіїв знижується до $30 \%$, що несприятливо впливає на вегетацію сільськогосподарських культур. Сильні (більше 15 м/с) вітри, які викликають пилові бурі, в середньому спостерігаються впродовж 41 доби на рік. Вони видувають поверхневий шар грунту та пошкоджують посіви [1].

Погодні умови завжди істотно впливають на реакцію пшениці озимої залежно від різних агротехнічних заходів - змінюють тривалість вегетаційного періоду, впливають на швидкість і спрямованість біохімічних процесів, що відбуваються в рослинах, впливають на хлібопекарські та посівні якості, впливають на ріст і розвиток рослин і багато інших показників. Прив'язка до гідротермічних особливостей року є необхідною умовою правильної оцінки реакції пшениці на застосування тих чи інших агротехнічних заходів.

Кліматичні умови району діяльності станції дозволяють вирощувати всі основні польові культури. Інтенсивне сніготанення, зливовий характер літніх опадів, сильні вітри зумовлюють ерозію грунтів. У літній період сільськогосподарські культури відчувають нестачу вологи, що посилюється під час суховіїв.

Проаналізувавши гідротермічний стан за роки дослідження 2017-2019 рр., можна сказати, що погодні умови були задовільними для вирощування пшениці озимої. На час сівби озимини продуктивної вологи вистачало для отримання своєчасних сходів, насіння проростало в середньому на 5-7 день після сівби. Відносно тепла погода осіннього періоду подовжувала вегетацію пшениці озимої, а ПОВ відмічалося в середньому у I декаді грудня. Перезимівля посівів проходила успішно [3; 7].

Осіння вегетація проходила в задовільних умовах. Рослини відійшли до перезимівлі у добре розвинутому стані. Погодні умови зими сприяли частковій вегетації в окремі декади зимового періоду.

Після припинення осінньої вегетації пшениці озимої науковцями Донецької державної сільськогосподарської дослідної станції були відібрані зразки рослин 3 кожної ділянки для визначення стану озимини на цей час (табл. 1).

Найвищими рослини були при використанні Меланоріз, МікоФренд+Гуміфренд, Меланоріз+ХелпРос (обробка насіння) + ГуміФренд (у фазі кущення) + Гуміфренд (у фазі прапорцевого листка).

Що стосовно коефіцієнту кущіння, то цей показник був приблизно однаковим на варіантах де використовували препарат Меланоріз, Мікофренд+Гуміфренд, Меланоріз+ХелпРост, МікоФренд+ХелпРост. 
Таблиця 1. Біометричні показники рослин пшениці озимої на момент припинення осінньої вегетації.

\begin{tabular}{|c|c|c|c|c|c|c|c|c|c|}
\hline \multirow{2}{*}{\multicolumn{2}{|c|}{ Варіант }} & \multicolumn{4}{|c|}{ Висота, см } & \multicolumn{4}{|c|}{ Коефіцієнт кущіння } \\
\hline & & I & II & III & Серед & I & II & III & Серел \\
\hline 1 & Контроль (без обробки) & 5 & 6 & 5 & 5,3 & 4,1 & 4,2 & 3,9 & 4,1 \\
\hline 2 & МікоФренд 1 л/т (насіння) & 6 & 6 & 6 & 6,0 & 4,1 & 4,4 & 4,8 & 4,4 \\
\hline 3 & Меланоріз 1 л/т (насіння) & 6 & 7 & 8 & 7,0 & 4,6 & 4,9 & 4,9 & 4,8 \\
\hline 4 & ГуміФренд 1 л/т (насіння) & 7 & 6 & 7 & 6,7 & 4,7 & 4,7 & 4,6 & 4,7 \\
\hline 5 & $\begin{array}{l}\text { МікоФренд } 1 \text { л /т + ГуміФренд } 0,8 \text { л/т } \\
\text { (насіння) }\end{array}$ & 8 & 7 & 6 & 7,0 & 4,9 & 4,7 & 4,7 & 4,8 \\
\hline 6 & Меланоріз 0,5 л/т + ГуміФренд 0,8 л/т & 7 & 6 & 6 & 6,3 & 4,6 & 4,6 & 4,7 & 4,6 \\
\hline 7 & $\begin{array}{l}\text { МікоФренд } 1 \text { л/т+ ХелпРост насіння } 1 \\
\text { л/т (насіння) }\end{array}$ & 6 & 7 & 7 & 6,7 & 4,7 & 4,6 & 4,8 & 4,7 \\
\hline 8 & $\begin{array}{l}\text { Меланоріз 0,5 л/т +ХелпРост насіння } 1 \\
\text { л/т (насіння) }\end{array}$ & 6 & 8 & 7 & 7,0 & 4,7 & 4,8 & 4,9 & 4,8 \\
\hline 9 & $\begin{array}{l}\text { ГуміФренд 0,4 л/га (початок } \\
\text { трубкування) }\end{array}$ & 7 & 6 & 7 & 6,7 & 4,7 & 4,6 & 4,8 & 4,7 \\
\hline 10 & $\begin{array}{l}\text { ГуміФренд 0,5 л/га (фаза прапорцевого } \\
\text { листка) }\end{array}$ & 7 & 7 & 6 & 6,7 & 4,8 & 4,7 & 4,7 & 4,7 \\
\hline \multicolumn{2}{|c|}{$\mathrm{HIP}_{0,5}$} & & & & 0,2 & & & & 0,1 \\
\hline
\end{tabular}

3 початку календарної весни за даними метеостанції у Донецькій області в регіоні були зафіксовані незначні опади.

Відновлення вегетації проходило в задовільних умовах, поступово, без різкого наростання позитивних температур.

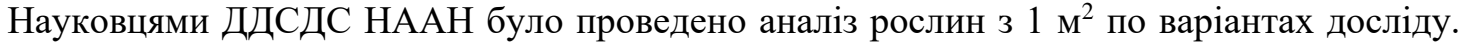
Після проведення необхідних вимірювань та розрахунків були отриманні наступні результати біометричних показників рослин пшениці озимої (табл. 2, рис. 1).

Що стосовно показників кількість стебел та коефіцієнт кущіння, то значну прибавку відносно контрольного варіанту забезпечило використання для обробки насіння суміші Меланоріз+ГуміФренд (+2157,6 шт./м2 або коефіцієнт кущіння 4,8) та суміші Меланоріз+ХелпРост ( +1812,8 шт./м2 або коефіцієнт кущіння 4,0). Всі інші варіанти не забезпечили збільшення цих показників відносно контрольного варіанту.

Таблиця 2. Біометричні показники рослин пшениці озимої залежно від використання препаратів, станом на 08.04.2019 р.

\begin{tabular}{|c|l|c|c|c|}
\hline № & \multicolumn{1}{|c|}{ Варіант } & $\begin{array}{c}\text { Середня } \\
\text { висота, } \\
\text { см }\end{array}$ & $\begin{array}{c}\text { Кількість } \\
\text { стебел, } \\
\text { шт./m }\end{array}$ & $\begin{array}{c}\text { Коефіцієнт } \\
\text { кущіння }\end{array}$ \\
\hline 1 & Контроль (без обробки) & 26 & 1378,1 & 3,1 \\
\hline 2 & МікоФренд 1 л/т (насіння) & 29 & 1800,0 & 4,0 \\
\hline 3 & Меланоріз 1 л/т (насіння) & 26 & 2045,5 & 4,5 \\
\hline 4 & ГуміФренд 1 л/т (насіння) & 27 & 2400,0 & 5,3 \\
\hline 5 & МікоФренд 1 л /т + ГуміФренд 0,8 л/т (насіння) & 27 & 1830,0 & 4,1 \\
\hline 6 & Меланоріз 0,5 л/т + ГуміФренд 0,8 л/т & 29 & 3535,7 & 7,9 \\
\hline 7 & МікоФренд 1 л/т+ ХелпРост насіння 1 л/т (насіння) & 27 & 2295,0 & 5,1 \\
\hline 8 & Меланоріз 0,5 л/т +ХелпРост насіння 1 л/т (насіння) & 26 & 3190,9 & 7,1 \\
\hline 9 & ГуміФренд 0,4 л/га (початок трубкування) & 26 & 2205,0 & 4,9 \\
\hline 10 & ГуміФренд 0,5 л/га (фаза прапорцевого листка) & 30 & 2600,0 & 5,8 \\
\hline НІР & & 0,5 & 13 & 0,2 \\
\hline
\end{tabular}

Як видно з рисунку 1, коренева система на цей час дуже добре розвинута не залежно від варіанту. 

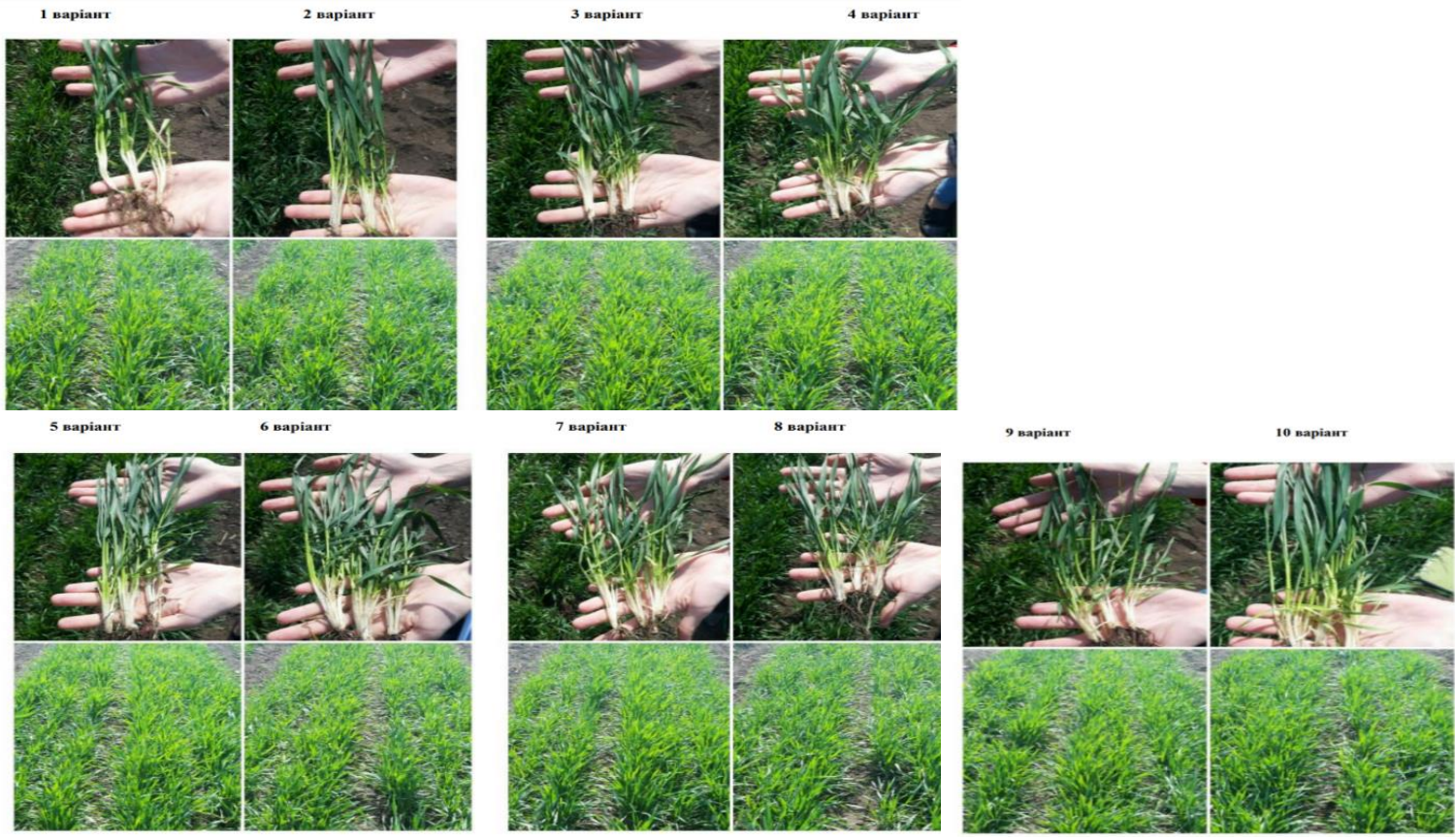

Рис. 1. Стан рослин пшениці озимої за варіантами станом на 08.04.2019p.

На момент повної стиглості зерна, залежно від варіанту, рослинами пшениці озимої були сформовані наступні показники (табл. 3, табл. 4).

Таблиця 3. Біометричні показники рослин пшениці озимої залежно від використання препаратів станом на 01.07.2019 p.

\begin{tabular}{|c|c|c|c|c|}
\hline № & Варіант & $\begin{array}{c}\text { Середня } \\
\text { висота, см }\end{array}$ & $\begin{array}{c}\text { Кількість } \\
\text { стебел, } \\
\text { шт./м² }\end{array}$ & $\begin{array}{l}\text { Коефіцієнт } \\
\text { кущіння }\end{array}$ \\
\hline 1 & Контроль (без обробки) & 92 & 601 & 1,6 \\
\hline 2 & МікоФренд 1 л/т (насіння) & 90 & 652 & 1,8 \\
\hline 3 & Меланоріз 1 л/т (насіння) & 88 & 809 & 2,2 \\
\hline 4 & ГуміФренд 1 л/т (насіння) & 89 & 833 & 2,2 \\
\hline 5 & МікоФренд 1 л /т + ГуміФренд 0,8 л/т (насіння) & 89 & 855 & 2,2 \\
\hline 6 & Меланоріз 0,5 л/т + ГуміФренд 0,8 л/т & 88 & 774 & 2,1 \\
\hline 7 & $\begin{array}{l}\text { МікоФренд } 1 \text { л/т+ ХелпРост насіння } 1 \text { л/т } \\
\text { (насіння) }\end{array}$ & 90 & 725 & 2,0 \\
\hline 8 & $\begin{array}{l}\text { Меланоріз 0,5 л/т +ХелпРост насіння } 1 \text { л/т } \\
\text { (насіння) }\end{array}$ & 89 & 698 & 2,0 \\
\hline 9 & ГуміФренд 0,4 л/га (початок трубкування) & 88 & 817 & 2,5 \\
\hline 10 & ГуміФренд 0,5 л/га (фаза прапорцевого листка) & 91 & 882 & 2,3 \\
\hline \multicolumn{2}{|c|}{$\mathrm{HIP}_{0.5}$} & 0,7 & 6,0 & 0,11 \\
\hline
\end{tabular}

Не залежно від варіанту використання препаратів, що вивчалися, суттєвого впливу на процеси кущіння рослин пшениці озимої не було. Це пов'язано, насамперед, зі сприятливими умовами проходження етапів органогенезу рослинами, тобто кількість продуктивної вологи та температурний режим сприяли доброму засвоєнню поживних речовин кореневою та вегетативною системою пшениці озимої, що в свою чергу знівелювало ефективність від використання запропонованих елементів [1]. Проте, використання препарату ГуміФренд на початку трубкування сприяло збільшенню коефіцієнту кущіння відносно контролю на 0,5 . 
Таблиця 4. Біометричні показники пшениці озимої сорту Перемога у фазі повної стиглості, станом на 01.07.2019 p.

\begin{tabular}{|c|c|c|c|c|c|}
\hline \multirow{2}{*}{ № } & \multirow{2}{*}{ Варіант } & \multicolumn{2}{|c|}{$\begin{array}{l}\text { Кількість } \\
\text { стебел, шт. }\end{array}$} & \multicolumn{2}{|c|}{$\begin{array}{c}\text { Коефіцієнт } \\
\text { кущіння }\end{array}$} \\
\hline & & $\begin{array}{l}\text { Загал., } \\
\text { шт./м² }\end{array}$ & $\begin{array}{c}\text { Прод., } \\
\text { шт./2 }\end{array}$ & загал. & прод. \\
\hline 1 & Контроль (без обробки) & 752 & 601 & 2,1 & 1,6 \\
\hline 2 & МікоФренд 1 л/т (насіння) & 815 & 652 & 2,2 & 1,8 \\
\hline 3 & Меланоріз 1 л/т (насіння) & 1011 & 809 & 2,8 & 2,2 \\
\hline 4 & ГуміФренд 1 л/т (насіння) & 1040 & 833 & 2,7 & 2,2 \\
\hline 5 & МікоФренд 1 л /т + ГуміФренд 0,8 л/т (насіння) & 1069 & 855 & 2,8 & 2,2 \\
\hline 6 & Меланоріз 0,5 л/т + ГуміФренд 0,8 л/т & 968 & 774 & 2,6 & 2,1 \\
\hline 7 & МікоФренд 1 л/т+ ХелпРост насіння 1 л/т (насіння) & 907 & 725 & 2,5 & 2,0 \\
\hline 8 & Меланоріз 0,5 л/т +ХелпРост насіння 1 л/т (насіння) & 873 & 698 & 2,5 & 2,0 \\
\hline 9 & ГуміФренд 0,4 л/га (початок трубкування) & 1020 & 817 & 3,1 & 2,5 \\
\hline 10 & ГуміФренд 0,5 л/га (фаза прапорцевого листка) & 1103 & 882 & 2,9 & 2,3 \\
\hline \multicolumn{2}{|r|}{$\mathrm{HIP}_{0,5}$} & 15,0 & 4,0 & 0,03 & 0,09 \\
\hline
\end{tabular}

Що стосовно показників структури урожаю, то ефективність застосування варіантів, що вивчалась була наступною (табл. 5).

На всіх варіантах застосування препаратів від вітчизняного виробника ТОВ «ТОРГОВИЙ ДІМ «БТУ-ЦЕНТР» призвело до збільшення маси 1000 насінин, але найвищим цей показник був на 8 варіанті при застосуванні препаратів Меланоріз+ХелпРост- 34,2, що більший за контроль на 2,1 г (6,5\%). 2 та 3 варіанти не зовсім вплинули на показник маса 1000 зерен залежно від контролю - 32,3 г. (більший на 0,6 \%).

Таблиця 5. Показники структури урожаю залежно від елементу технології, станом на 01.07.2019 p.

\begin{tabular}{|c|l|c|c|c|}
\hline \multicolumn{1}{|c|}{ № } & \multicolumn{1}{|c|}{ Варіант } & $\begin{array}{c}\text { Довж. } \\
\text { колосу, } \\
\text { см }\end{array}$ & $\begin{array}{c}\text { Кіл. зерен } \\
\text { у колосі, } \\
\text { шт. }\end{array}$ & $\begin{array}{c}\text { Маса } \\
1000 \\
\text { зерен, г }\end{array}$ \\
\hline 1 & Контроль (без обробки) & 7,4 & 25,9 & 32,1 \\
\hline 2 & МікоФренд 1 л/т (насіння) & 7,9 & 32,7 & 32,3 \\
\hline 3 & Меланоріз 1 л/т (насіння) & 7,8 & 37,1 & 32,3 \\
\hline 4 & ГуміФренд 1 л/т (насіння) & 7,8 & 35,6 & 32,5 \\
\hline 5 & МікоФренд 1 л /т + ГуміФренд 0,8 л/т (насіння) & 7,8 & 36,5 & 33,0 \\
\hline 6 & Меланоріз 0,5 л/т + ГуміФренд 0,8 л/т & 8,0 & 35,8 & 31,9 \\
\hline 7 & МікоФренд 1 л/т+ ХелпРост насіння 1 л/т (насіння) & 7,9 & 28,7 & 32,0 \\
\hline 8 & Меланоріз 0,5 л/т +ХелпРост насіння 1 л/т (насіння) & 7,8 & 36,8 & 34,2 \\
\hline 9 & ГуміФренд 0,4 л/га (початок трубкування) & 7,6 & 32,4 & 32,3 \\
\hline 10 & ГуміФренд 0,5 л/га (фаза прапорцевого листка) & 7,9 & 34,8 & 33,2 \\
\hline НІР & & 0,2 & 3,0 & 0,1 \\
\hline
\end{tabular}

Найбільша довжина колосу $(8,0$ см) була при комплексному використанні препаратів Меланоріз + ГуміФренд у фазі кущення та у фазі колосіння. Кращій вплив на показник кількості зерен у колосі виявив 3 варіант при використанні препарату Меланоріз - 37,1 шт., інші варіанти також суттєво вплинули на показник кількість зерен у колосі залежно до контролю.

Покращення показників структури урожаю пшениці озимої сорту Перемога порівняно 3 контрольним варіантом істотно вплинуло на збільшення урожайності культури (табл. 6). 
Таблиця 6. Урожайність зерна пшениці озимої сорту Перемога, 2019 р.

\begin{tabular}{|c|l|c|c|c|}
\hline \multirow{2}{*}{ № } & \multicolumn{1}{|c|}{ Варіант } & \multirow{2}{*}{$\begin{array}{c}\text { Урожайність } \\
\text { т/га }\end{array}$} & \multicolumn{2}{|c|}{ Прибавка } \\
\cline { 3 - 5 } & & 8,2 & - & т/га \\
\hline 1 & Контроль (без обробки) & 8,6 & $+0,4$ & $+4,88$ \\
\hline 2 & МікоФренд 1 л/т (насіння) & 9,7 & $+1,5$ & $+18,29$ \\
\hline 3 & Меланоріз 1 л/т (насіння) & 9,1 & $+0,9$ & $+10,98$ \\
\hline 4 & ГуміФренд 1 л/т (насіння) & 9,3 & $+1,1$ & $+13,41$ \\
\hline 5 & МікоФренд 1 л/т ГуміФренд 0,8 л/т (насіння) & 8,8 & $+0,6$ & $+7,32$ \\
\hline 6 & Меланоріз 0,5 л/т + ГуміФренд 0,8 л/т & 8,5 & $+0,3$ & $+3,66$ \\
\hline 7 & МікоФренд 1 л/т+ ХелпРост насіння 1 л/т (насіння) & 8,7 & $+0,5$ & $+6,10$ \\
\hline 8 & Меланоріз 0,5 л/т +ХелпРост насіння 1 л/т (насіння) & 8,4 & $+0,2$ & $+2,44$ \\
\hline 9 & ГуміФренд 0,4 л/га (початок трубкування) & 8,3 & $+0,1$ & $+1,22$ \\
\hline 10 & ГуміФренд 0,5 л/га (фаза прапорцевого листка) & 0,1 & & \\
\hline НІР & & & \\
\hline
\end{tabular}

Найвищий рівень урожайності пшениці озимої було отримано при обробці насіння мікоризним препаратом Меланоріз 1 л/т, прибавка до контрольного варіанту склала $+1,5$ т/га. Економічно доцільним виявилися і варіанти 4, 5, 6, прибавка яких складала відповідно $+0,9$, $+1,1,+0,6$ т/га.

Висновки. Проаналізувавши результати польового досліду було встановлено, що на початкових етапах органогенезу пшениці озимої застосування препарату ГуміФренд має позитивний вплив на розвиток рослин, що в подальшому простежується в показниках структури урожаю.

Аналіз впливу системи препаратів Меланоріз, МікоФренд, ХелпРост на адаптивні властивості рослин пшениці озимої дозволяє зробити висновок, що у рослин пшениці озимої сорту Перемога значно посилюються адаптивні властивості до несприятливих умов вирощування.

\section{ЛІТЕРАТУРА}

1. Вінюков О. О. Вплив біопрепаратів і регуляторів росту рослин на показники якості зерна озимої пшениці. Матеріали Всеукраӥнської науково-практичної конференції молодих вчених $і$ спеціалістів 25-26 травня 2016 р. / НААН, ДУ ІЗК НААН, М-во аграр. політики та прод. України, Укр. ін-т експертизи сортів рослин. Вінниця 2016. С.47-48.

2. Гирка А.Д., Тарасенко О.А., Кротінов І.В. Особливості ростових процесів рослин озимої пшениці в осінній період вегетації залежно від строків сівби. Бюлетень Інституту зернового господарства УААН. 2009. № 36. С. 20-24.

3. Гирка А.Д. Агробіологічні основи формування продуктивності озимих та ярих зернових культур у Північному Степу України. дис. доктор с.г. наук. Дніпропетровськ, 2015. С. 356.

4. Доспехов Б.А. Методика полевого опыта. - 5-е изд., доп. и перераб. Агропромиздат, 1985. С. 351

5. Маслак О., Ільченко В., Ільченко О. Ефективність вирощування пшениці озимої. [Електронний ресурс]. Режим доступу: http://repo.sau.sumy.иа

6. Моргун В.В., Санін Є.Ю., Швартау В.В. Клуб 100 центнерів. Сучасні сорти та системи живлення і захисту озимої пшениці. Київ: Логос. 2014. С. 148

7. Технології вирощування зернових і технічних культур. ННЦ «IАЕ», 2008. С. 720 